\title{
UNCTAD's Technical Cooperation Programme on Consumer Protection for Latin America: COMPAL
}

\author{
Arnau Izaguerri ${ }^{1}$
}

Received: 31 December 2021 / Accepted: 3 January 2022 / Published online: 5 February 2022

(c) The Author(s), under exclusive licence to Springer Science+Business Media, LLC, part of Springer Nature 2022

\begin{abstract}
UNCTAD's mandate is threefold. It facilitates consensus building, provides research and analysis and offers technical assistance and capacity building to developing countries and countries with economies in transition. Since the 1980s, UNCTAD has been providing technical assistance and capacity building for those same countries in adopting or revising consumer protection legislation and policies, also to increase complementarity with trade and industrial policies and as a means of achieving Sustainable Development Goals. UNCTAD's COMPAL Programme has had a significant and positive impact in improving consumer protection regimes and institutions in Latin America. The EU and UNCTAD should partner in continuing and expanding COMPAL in the years to come for the benefit of Latin American and European consumers.
\end{abstract}

Keywords UNCTAD · Latin America · Consumer Protection · COMPAL · European Union

\section{Introduction: The Work of UNCTAD on Consumer Protection}

The United Nations Conference on Trade and Development (UNCTAD) is the focal point, within the United Nations system, for the integrated treatment of trade and development and interrelated issues in the areas of finance, technology, investment, services and sustainable development. It is also the focal point for consumer protection issues. The UNCTAD Ministerial Conferences of Accra (UNCTAD, 2008), Doha (UNCTAD, 2012), Nairobi (UNCTAD, 2014) and Bridgetown (UNCTAD, 2021) entrusted UNCTAD with the mandate to conduct analysis and research and help developing countries and countries with economies in transition to formulate and implement competition and consumer protection policies. UNCTAD was formally mandated to serve as a focal point for consumer protection by the United Nations General Assembly in resolution 70/186 of 22 December 2015, which also revised the United Nations Guidelines for Consumer Protection (Guidelines).

Arnau Izaguerri

arnau.izaguerri@gmail.com

1 Economic Affairs Officer, United Nations Conference On Trade and Development, Geneva, Switzerland 
The Guidelines are the only global instrument on consumer protection. As described by the General Assembly, they are "a valuable set of principles for setting out the main characteristics of effective consumer protection legislation, enforcement institutions and redress systems and for assisting interested Member States in formulating and enforcing domestic and regional laws, rules and regulations that are suitable to their own economic and social and environmental circumstances, as well as promoting international enforcement cooperation among Member States and encouraging the sharing of experiences in consumer protection." The Guidelines were first adopted by the General Assembly in resolution 39/248 of 16 April 1985 and later expanded by the Economic and Social Council in resolution E/1999/INF/2/Add.2. UNCTAD promotes the Guidelines and encourages interested Member States to create awareness of the many ways in which Member States, businesses and civil society can promote consumer protection in provision of public and private goods and services (United Nations Guidelines for Consumer Protection, 2015).

UNCTAD's mandate is threefold: It facilitates consensus building, provides research and analysis and offers technical assistance and capacity building to developing countries and countries with economies in transition.

UNCTAD facilitates consensus building in the field of consumer protection by hosting the Intergovernmental group of experts on consumer protection law and policy, ${ }^{1}$ which meets annually in Geneva and recently also online. Its first function, as set out in the Guidelines, is to "provide an annual forum and modalities for multilateral consultations, discussion and exchange of views between Member States on matters related to the guidelines, in particular their implementation and the experience arising therefrom." This Group answers a long-standing call from consumer advocates to establish a United Nations body responsible for consumer protection. In 2021, the Group had met five times under the auspices of UNCTAD.

More importantly, the Group reports to the quinquennial United Nations Conference to Review all Aspects of the Set of Multilaterally Agreed Equitable Principles and Rules for the Control of Restrictive Business Practices. This ministerial meeting is the highest level on consumer protection within the United Nations. It is directly mandated by the United Nations General Assembly and provides an opportunity for ministers, heads of competition and consumer protection authorities and senior officials of Member States to discuss competition and consumer protection policies, at the national and international levels, as tools for sustainable development, economic growth and competitiveness.

The Conference decides on UNCTAD's programme of work on competition and consumer protection for the following five years and can submit resolutions for consideration by the General Assembly, as was the case with the revised United Nations Guidelines for Consumer Protection. Since General Assembly resolutions target Member States, it is a way for consumer protection decisions to irradiate to all other areas of government action and to do so at the highest level. For example, the Guidelines contain a chapter on financial services which is directed not only to consumer protection agencies but also to ministries of finance, financial sector regulators and central banks. The Guidelines have thus been instrumental in promoting consumer protection among all interested government authorities.

UNCTAD also undertakes research and analysis in the field of consumer protection. Since receiving its official mandate in 2015, UNCTAD has published a revised Manual on Consumer Protection, Guidelines on consumer protection, on agency structure and

\footnotetext{
1 https://unctad.org/topic/competition-and-consumer-protection/intergovernmental-group-of-experts-onconsumer-protection (accessed 3 September 2021).
} 
effectiveness, and on business engagement as well as a publication on achieving the Sustainable Development Goals through Consumer Protection. These publications provide practical tools for policymakers and enforcers to better implement consumer protection policies. They help to spread good practices and enhance capacities of developing countries and economies in transition to strengthen protection of their consumers.

Since the 1980s, UNCTAD has been providing technical assistance and capacity building for developing countries and countries with economies in transition in adopting or revising consumer protection legislation and polices, also to increase complementarity with trade and industrial policies and as a means of achieving the Sustainable Development Goals. ${ }^{2}$ Technical cooperation at UNCTAD is demand driven, which means governments direct a request to the UNCTAD secretariat specifying what kind of assistance they wish to receive. Technical cooperation is supported by extra-budgetary funds of UNCTAD: requests must be funded by beneficiary countries or development partners (i.e., donors) in an ad hoc manner. To ensure buy-in and commitment by beneficiary countries, all activities are planned and implemented in close cooperation with governmental competition and consumer protection agencies, as well as other national, regional and global networks, where appropriate. The UNCTAD strategy "focuses on the following aspects and issues: (i) technical assistance for consumer protection policy and regulation; (ii) an enabling environment for the private sector; [...] (iii) expanded regional focus; (iv) follow-up and impact assessment of activities" (UNCTAD, 2019.)

UNCTAD's technical assistance and cooperation takes various forms. UNCTAD supports countries in developing and revising consumer protection policies, legislative and institutional frameworks. It also assists in drafting legislation, in line with regional and international commitments and best practices. UNCTAD supports the design of consumer protection agencies to improve institutional efficiency and helps build human capacity through bespoke training programmes. Finally, UNCTAD can also facilitate exchange of staff and internships among consumer protection authorities. In the framework of technical cooperation, UNCTAD undertakes research and analysis, reports, guidelines and handbooks; it organizes trainings, workshops and study visits, and it hosts high-level conferences and seminars.

One specific product within the technical cooperation framework of UNCTAD that is attracting much attention is Voluntary Peer Reviews of Consumer Protection Law and Policy (peer reviews), as this was only mandated in the latest revision of the Guidelines in 2015. Its purpose is to "provide an external and independent assessment of the effectiveness of consumer protection law and policy in a given country; to identify the challenges to be addressed and areas to be improved in the legal and institutional frameworks, thereby contributing to enhancing quality, efficiency and consumer protection regimes; to assess the consumer protection awareness of relevant stakeholders and their contributions in this area; to formulate and recommend appropriate measures, designed in consideration of the economic and developmental particularities of each country, to address these challenges; and, where appropriate, to assist countries in implementing the recommendations by developing a capacity-building project in consultation with the country concerned" (UNCTAD, 2017.) While UNCTAD has been conducting peer reviews in the area of competition for over fifteen years, this is a novelty in the field of consumer protection. So far, Morocco, Indonesia, Peru and Chile have undergone peer reviews since 2018.

$\overline{2}$ https://unctad.org/en/PublicationChapters/tc2015d1rev1_S03_P01.pdf (accessed 3 September 2021). 
UNCTAD's technical cooperation activities that require funding need to secure resources from developing partners, be that Member States or UN funds, or from beneficiary countries themselves. The most ambitious programmes are usually funded by developed Member States. The United Nations Development Assistance Framework can also mobilize resources for projects, which need to fit in wider development programmes. Traditionally, beneficiary countries only assume the costs of activities whose benefit accrues directly to them, which are usually narrower in time and scope.

In summary, UNCTAD's work on consumer protection has both a political and a practical dimension. The intergovernmental machinery allows for global consensus on consumer protection and, when endorsed by the General Assembly, also to irradiate to other branches of government. In practical terms, UNCTAD's research and analysis, technical assistance and capacity building inform law and policy improvement and contribute to building national capacities, especially in developing and transition economies.

\section{The COMPAL Programme for Latin America: Objectives and Achievements}

UNCTAD's Programme on strengthening institutions and capacities in competition and consumer protection for Latin America (COMPAL) has been funded by the Swiss Cooperation Agency-SECO—since 2003. It is the longest and most successful of UNCTAD's programmes in the field of competition and consumer protection. COMPAL is the only programme on consumer protection to include seventeen Latin American countries, and all its activities have a regional approach, meaning that the aim is to improve the capacities of all its members and to deepen cooperation among them.

\section{Evolution}

As summarized in the COMPAL website, ${ }^{3}$ the programme began with a series of studies in 2003, assessing the needs and priorities of five selected countries: Bolivia, Costa Rica, El Salvador, Nicaragua and Perú. The first phase of the programme began in 2004 (COMPAL I), for these 5 countries. An independent evaluation in 2007 confirmed positive feedback from the beneficiary countries, so SECO decided to fund a second phase of the programme, COMPAL II, running from 2009 to 2013. COMPAL II was directed to the same beneficiaries plus Colombia. Since 2009, eleven more countries have joined, self-financing their participation. In 2015, UNCTAD began implementing the third phase of the programme (COMPAL III), focusing efforts on consolidating acquired capacities and deepening regional cooperation. COMPAL also provides the private sector with tools to ensure voluntary compliance and empowering global consumers in the twenty-first century. SECO's financial contribution ended in August 2018, and programme activities that are being pursued are funded entirely by beneficiary countries. These activities include the COMPAL Forum on consumer protection, and the possible relaunch of the INDECOPI-COMPAL School for government officials on consumer protection.

Currently, COMPAL beneficiaries are the competition and consumer protection governmental agencies of seventeen Latin American countries. These are the following:

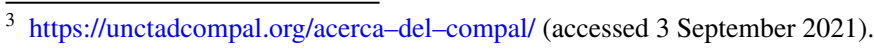


Argentina, Bolivia, Brazil, Chile, Colombia, Costa Rica, the Dominican Republic, Ecuador, El Salvador, Guatemala, Honduras, Mexico, Nicaragua, Panama, Paraguay, Perú and Uruguay.

\section{COMPAL III (2015-2018)}

The third phase of COMPAL, and the last to be financially supported by SECO, was implemented between February 2015 and August 2018. COMPAL III had two main objectives:(i) to sustainably strengthen legal frameworks and capacities in regard to competition and consumer protection through consolidation of capacities acquired during the first phases of COMPAL and through enhanced regional cooperation; and (ii) to strengthen support and compliance of the private sector with competition and consumer protection laws and policies through provision of advice and guidance. UNCTAD implemented $100 \%$ of its planned activities for COMPAL III and $99.3 \%$ of its budget, achieving all outcomes. COMPAL III implemented 36 individual activities of which 18 related to consumer protection. The following paragraphs describe only the activities that relate to consumer protection and that have the highest impact. After 2018, some COMPAL activities continue through self-funding by beneficiary countries and support from the UNCTAD secretariat.

\section{Activities}

Regarding consumer protection, the first objective on strengthening legal frameworks and reinforcing regional cooperation was pursued through activities involving exchange of experience, consensus building, training, and research and analysis. Of these, six were particularly impactful: the annual meeting of the COMPAL Forum on consumer protection; Workshops on Competition and Consumer Protection; the INDECOPI-COMPAL School for government officials; Latin American Regional training for judges on competition and consumer protection; a contest for exchange of staff; and research on cooperation among COMPAL members.

The International Forum on Consumer Protection was (and still is) organized on an annual basis by UNCTAD under the COMPAL framework. The Forum has consolidated over the years as the only open forum in Latin America to address consumer protection issues with a regional focus, gathering government officials, consumer associations, business representatives, academia and practitioners. In 2015 and 2017, COMPAL beneficiaries graded the Forum as the highest impact activity.

During COMPAL III, the Forum was held in Cuzco, Perú (2015); Guanacaste, Costa Rica (2016) and Mendoza, Argentina (2017). After COMPAL III, the Forum was held in Guadalajara, Mexico (2018), San Salvador, El Salvador (2019) ${ }^{4}$ and Lisbon, Portugal (2021 and online)..$^{5}$ The COMPAL Forum is attended by an average of 15 COMPAL consumer protection agencies, as well as observer countries and institutions such as: Canada, Germany, the Republic of Korea, Portugal, Spain, the USA, and Consumers International, with an average annual attendance of 100 participants.

\footnotetext{
4 https://unctadcompal.org/eventos/ (accessed 3 September 2021).

5 https://unctad.org/meeting/tenth-international-consumer-protection-forum-compal-programme (accessed 25 November 2021).
} 
The COMPAL Forum found a perfect synergy with the other major event on consumer protection in Latin America: The Iberoamerican Consumer Protection Governmental Agencies Forum, which is restricted to consumer protection governmental agencies. Since these fora are organized back-to-back, public policy issues discussed in the former can percolate into intergovernmental agreements in the latter.

Workshops on Competition and Consumer Protection were designed as an innovative space for policy discussion among government officials from competition and consumer protection agencies. Their objective was to facilitate exchange of experience and to identify synergies among the two domains to improve policies. The workshops covered crosscutting issues of investigative techniques (Cartagena, Colombia in 2015), regulated sectors (Antigua, Guatemala in 2016), and digital markets (Montevideo, Uruguay in 2017).

The INDECOPI-COMPAL School of competition and consumer protection was a new initiative born during COMPAL III by agreement between the Peruvian agency INDECOPI and UNCTAD. The School provided one course on consumer protection and one on competition each year while in operation. This consisted of a one-week intensive course in Lima for 30 case-handlers in charge of the subject-matter of the course (two per country maximum) by leading international experts, with strong emphasis on practical experience, and a six-month replication in home agencies.

The INDECOPI-COMPAL School was regarded by COMPAL beneficiaries and other stakeholders as a regional centre of excellence for training civil servants on competition and consumer protection. A rigorous selection process was set up to admit students. Applications were usually double the amount of available spaces for the intensive course in Lima. Around $20 \%$ of students paid their transportation costs directly, when the home agency could not cover them. Professors at the INDECOPI-COMPAL School highlighted its high-level exchanges and the uniqueness of reaching regional conclusions and solutions to common problems. The INDECOPI-COMPAL School provided the following courses on consumer protection:

1. Consumer protection in electronic commerce

2. Consumer protection in financial services

3. Consumer education and business compliance

4. Alternative dispute resolution for consumer disputes.

In all (including competition courses), the INDECOPI-COMPAL School trained 2600 experts, $100 \%$ of participants improved their technical capabilities, and beneficiary agencies reported an increase of $60 \%$ in their institutional capacities on the issues covered by the courses. This activity was consistently ranked among the top three of the most useful activities for COMPAL beneficiaries as it strengthened capacities and regional cooperation at the same time. INDECOPI volunteered to relaunch the INDECOPI-COMPAL School in the area of consumer and online to pursue this activity as of 2022; consultations for this purpose are ongoing between Peru and UNCTAD.

Latin American Regional training for judges on competition and consumer protection operated as a pilot activity. COMPAL beneficiary countries identified serious lacunae in the capacities of the judicial power to efficiently enforce competition and consumer protection. COMPAL decided to replicate the success of the INDECOPI-COMPAL School to direct it to judges. The activity was agreed between the School of Judges of Perú (AMAG) and UNCTAD in October 2016 for two courses: one on competition and one on consumer protection, gathering 50 judges for each course from all COMPAL 
countries. The course on consumer protection was entitled: Judicial protection of consumer rights (15-17 November 2017).

In order to encourage exchange of staff among COMPAL members, thus reinforcing South-South cooperation, COMPAL launched a one-year low budget activity. This took the form of a contest for exchange of staff on high impact projects. This activity was ranked with the highest impact in 2016. It had an initial contribution of US\$16,000 and raised over US\$ 40,000 from beneficiaries. The award-winning proposals for consumer protection were from Chile and Uruguay, whose officials travelled to Mexico to learn about its consumer online dispute resolution. As a result, Chile and Uruguay set up online claims handling and/or dispute resolution six months after the activity ended. Further, a Memorandum of Understanding on this issue was signed between Mexico and Uruguay shortly thereafter.

Research and analysis on consumer protection produced by COMPAL was contained in the Report on Cooperation among COMPAL members: Evolution and Perspectives (COMPAL Cooperación entre los miembros de COMPAL, 2018a, 2018b, 2018c). It was commissioned to independent expert Hebert Tassano, who led the competition and consumer protection agency of Perú, and María Fe Plaza, an international cooperation expert. The report found that 52\% of COMPAL beneficiaries believe that COMPAL serves to enhance cooperation through easier exchanges and $36 \%$ found that COMPAL was instrumental in engaging in new formal cooperation agreements. The report also analysed all other regional initiatives on competition and consumer protection (Asia-Pacific Economic Cooperation, the Consumer Safety and Health Network, the Iberoamerican Consumer Protection Forum, the Latin American Competition Forum and the Regional Centre for Competition [currently inactive]). It highlighted that COMPAL has the largest membership and that it has set up constructive partnerships with all other initiatives, thus avoiding duplication. Given the high engagement of beneficiary countries, the Report concluded that COMPAL should pursue a fourth phase. This fourth phase has not yet come about due to lack of funds.

The second objective of COMPAL III was to strengthen compliance by the private sector of competition and consumer protection laws and policies through provision of advice and guidance. The donor country decided this objective would only be pursued for Colombia and Perú, its priority countries. In the field of consumer protection, this objective was pursued through drafting guidelines on compliance and awareness-raising workshops.

COMPAL mandated Bernardo Altamirano, former head of the consumer protection agency in Mexico and current director general of the private sector federation Better Business Bureau in Mexico, to draft Guidelines on Business Compliance for Colombia (COMPAL, Guía para facilitar al sector empresarial el cumplimiento legal de sus obligaciones y derechos en materia del marco jurídico de protección al consumidor y competencia económica (Colombia), 2018) and Perú (COMPAL, Manual preliminar para facilitar al sector empresarial el cumplimiento legal de sus obligaciones y derechos en materia del marco jurídico de protección al consumidor y competencia económica (Perú), 201). The publication reviews literature and experience regarding compliance programmes. It proposes a structure for consumer protection agencies to present and propose compliance programmes to businesses. As this publication is targeted at Colombia and Perú, it links compliance programmes to their national legal framework of consumer protection, comprising substantive and procedural obligations, including sanctions for breaches of consumer law.

In order to increase private sector awareness, COMPAL organized two workshops at the request of Colombia and Perú. These proved very efficient in supporting the strategic priorities of governmental agencies. The first was entitled "Promoting competition and 


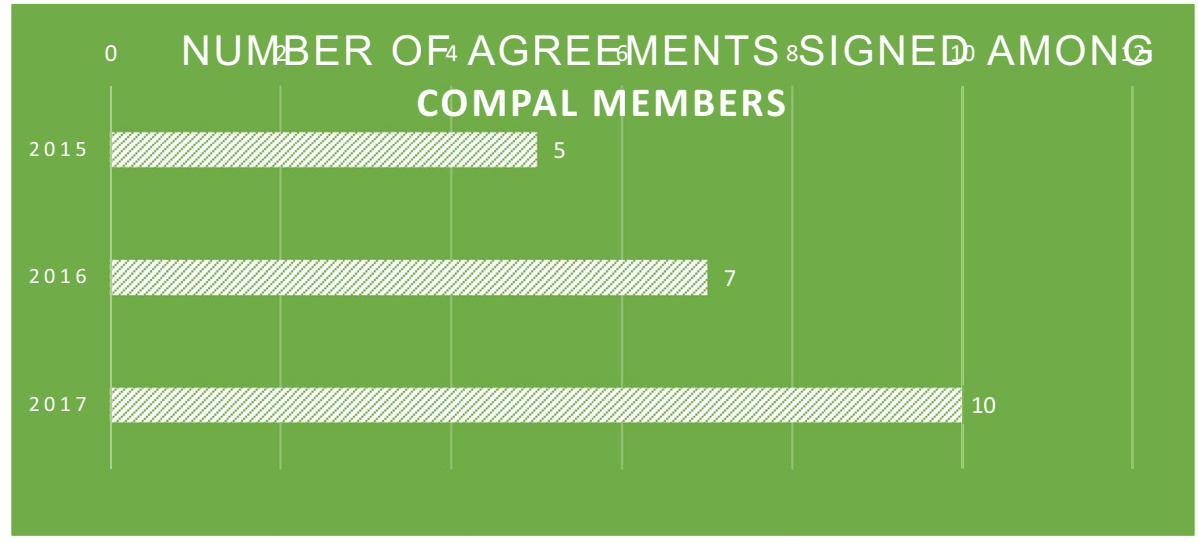

Fig. 1 Number of cooperation agreements signed among COMPAL member countries

consumer protection in the World Cup FIFA Russia 2018, Lima, 25 April 2018" and the second "Unfair practices in consumer protection, Bogotá 29 May 2018."

\section{Achievements}

COMPAL III recorded numerous achievements. As shown in Fig. 1, 60\% of beneficiary countries have undertaken law reform, and COMPAL played a direct role in preparation of 15 national laws. Regional cooperation was strengthened with a $50 \%$ yearly increase of cooperation agreements among beneficiary countries (from 5 to 10 ); for $36 \%$ of them COMPAL was instrumental, as reported by beneficiary countries.

Source: author.

The programme's website currently displays a library with all COMPAL publications and documentation (371 items) and has been visited over 13,000 times. COMPAL's regional training centre (INDECOPI-COMPAL School) trained 2600 experts; $100 \%$ of participants improved their technical capabilities; and beneficiary agencies reported an increase of $60 \%$ in their institutional capacities on the issues covered by the course.

\section{The Impact of European Union Experience on COMPAL Activities}

The European Union (EU) and its acquis communautaire does not have a direct relationship with COMPAL, although their influence can be felt at different levels. Firstly, the donor, Switzerland, is a member of the European Free Trade Association, which brings it closer to the EU experience. However, Switzerland did not express interest in advancing any particular policy option within the programme and left substantive decision making and implementation to UNCTAD. It is worth mentioning that the activity Workshops on Competition and Consumer Protection were all held at the premises of the Spanish Cooperation Training Centres (AECID, 2019) in Cartagena, Antigua and Montevideo. This was the only direct financial contribution by an EU Member State to COMPAL III.

Secondly, the EU has entered into various regional trade agreements with COMPAL members. The EU and the Central American region concluded an Association Agreement, signed on 29 June 2012. The EU has a comprehensive Trade Agreement with Colombia 
and Perú, which has been provisionally applied, with Perú since 1 March 2013 and with Colombia since 1 August 2013. On 1 January 2017, Ecuador joined this trade agreement. On 28 June 2019, the EU and MERCOSUR reached political agreement for an upcoming trade agreement, although this is still under review due to opposition by some EU Member States. Some of these treaties contain provisions directly addressing competition matters (for example, Central America), but not expressly consumer protection.

The lack of substantive agreements on consumer protection between the EU and COMPAL members has entailed that the acquis communautaire has influenced COMPAL activities in a soft manner. This is not to say that EU influence is not significant as its acquis has been shared, discussed and considered in numerous activities, particularly in the COMPAL Forum on consumer protection and in the INDECOPI-COMPAL School for government officials.

In the context of the annual meeting of the COMPAL Forum on consumer protection, EU legal frameworks and initiatives were presented on various occasions. In the Cuzco courses of $2015,{ }^{6}$ Portugal and Spain presented the EU experience in alternative dispute resolution and industry self-regulation respectively. Spain shared EU Directive, 2013/11 on alternative dispute resolution for consumers and Regulation 524/2013 on online dispute resolution for consumers, both of 21 May 2013. These were considered as a source of inspiration for national and regional initiatives in the field. At that time, only Mexico had years of experience in providing online dispute resolution (Concilianet). Brazil and Colombia had just launched their own national initiative (consumidor.gov and SIC Facilita, respectively). Interest in building regional online dispute resolution for consumers has grown ever since, and the EU remains the only regional reference. On self-industry regulation, Portugal presented the EU experience in the fields of marketing and advertising.

In the COMPAL Forum of 2016 in Guanacaste, ${ }^{7}$ Portugal presented the EU experience in protection of consumers on social media, and the then recent EU Regulation 2016/679 on the protection of natural persons with regard to the processing of personal data. This discussion was timely, as some COMPAL members were studying adoption of consumer data protection laws. The issue is still not resolved in Latin America, especially as new initiatives such as the comprehensive EU General Data Protection Regulation come into play.

In the COMPAL Forum of 2017 in Mendoza, ${ }^{8}$ Germany and Portugal presented initiatives under the framework of the European Digital Single Market Strategy, in particular the draft Directive on digital contents and digital services and the draft regulation to enhance cross-border enforcement of consumer protection laws. Both instruments were discussed in the light of analogous cooperation frameworks in the Andean Community and MERCOSUR, although none yet allow for coordinated cross-border penalties.

The INDECOPI-COMPAL School for government officials ${ }^{9}$ transmitted best practices stemming from EU practices at all its courses. The first course on "Consumer protection in e-commerce in Latin America" of 2015 included a lecture by a professor of commercial law from Olavide University, Spain. He presented Directives, 2000/31, 2011/83 and 2013/11 on e-commerce, consumer rights and alternative dispute resolution. This was

\footnotetext{
6 https://unctadcompal.org/events/v-foro-internacional-de-proteccion-al-consumidor-hacia-una-prote ccion-global/ (accessed 3 September 2021).

7 https://unctadcompal.org/events/1480/ (accessed 3 September 2021).

8 https://unctadcompal.org/events/vii-reunion-anual-del-foro-internacional-proteccion-al-consumidorlas-relaciones-consumo-la-confianza-escenario-global/ (accessed 3 September 2021).

9 https://unctadcompal.org/escuela-indecopi-compal/ (accessed 3 September 2021).
} 
particularly relevant as at the time only Colombia had specific legislation on consumer rights in electronic commerce. The course included a practical case on digital terms and conditions extracted from European case law, which showed the shortcomings of not having bespoke legislation on the issue. Costa Rica and El Salvador introduced amendments to their proposed bills on consumer rights to cover electronic commerce; El Salvador modified its criteria for evaluating proof obtained by electronic means, while Colombia and Paraguay reviewed their enforcement procedures for electronic commerce.

The second course of the INDECOPI-COMPAL School for government officials on "Financial consumers in Latin America" (2016) included participation by an enforcer from the Catalan Consumer Agency. The practical cases discussed covered EU legislation and case law relating to unfair terms in consumer contracts, consumer credit, over-indebtedness and interest rate calculation. This course inspired El Salvador to include provisions on tied credit in its consumer protection law, while Uruguay launched new enforcement activities in the financial services sector.

The third course of the INDECOPI-COMPAL School on "Consumer education and business guidance" $(2017)^{10}$ also included participation by the Catalan Consumer Agency. On this occasion, various EU initiatives were discussed, such as the European agenda for the collaborative economy, the Green Paper on consumer protection and the Opinion of the European Economic and Social Committee on the 'Sharing economy and self-regulation.' The course provided an in-depth picture of current trends in the European Union regarding consumer education and business guidance, including self-regulation and co-regulation. This course supported Chile's efforts in enhancing co-regulation in the country. Costa Rica, El Salvador and Perú reported improvements in communication strategies with consumers.

The fourth and last course of the INDECOPI-COMPAL School addressed "Alternative dispute resolution" in 2018. ${ }^{11}$ The course reviewed existing initiatives at national and regional level, the most relevant of which being the EU online dispute resolution platform. Additionally, a professor from Universidade Nova de Lisboa and the head of a consumer arbitration centre presented the different avenues for alternative dispute resolution within the EU legal framework, in the light of EU Directive, 2013/11. Following this course, Mexico and Uruguay began implementing their memorandum on transferring knowledge for implementation of online dispute resolution in Uruguay. Chile and Perú improved their projects to launch similar services, and all COMPAL beneficiary countries requested UNCTAD to assess the feasibility of establishing a regional online dispute resolution mechanism. Possible future courses of the INDECOPI-COMPAL School in the area of consumer protection are being discussed between Peru and UNCTAD.

\section{Future Cooperation between COMPAL and the European Union}

An independent evaluation of the COMPAL Programme found it to be "a successful technical assistance programme attracting attention by other countries to learn from and participate in." (Devfin Advisers, 2012) The expected impact of the COMPAL III phase was

\footnotetext{
10 https://unctadcompal.org/events/programa-formacion-especializada-la-escuela-indecopi-compal-prote ccion-al-consumidor/ (accessed 3 September 2021).

11 https://unctadcompal.org/events/cuarto-programa-formacion-especializada-la-escuela-indecopicompal-proteccion-al-consumidor-mecanismos-alternativos-conflictos-consumo/ (accessed 3 September 2021).
} 
to become self-sustaining after the exit of the donor, SECO. However, as with other UNCTAD technical cooperation programmes, the involvement of donors is always necessary to sustain activities.

COMPAL evolved towards self-sustainability throughout its three phases. In the first stage of the programme (2003-2007), donor SECO financed 100\% of the activities. In the second stage of the programme (2009-2012), the distribution of responsibilities for financing activities evolved to $80 \%$ SECO and $20 \%$ beneficiaries. In the third phase (2015-2018), the programme took a leap towards self-sustainability: the weighted distribution over the global budget was approximately 35\% from SECO and 65\% from beneficiaries. If fixed costs are subtracted, such as those related to COMPAL officials' salaries, distribution reached was $30 \%$ via SECO and $70 \%$ via beneficiaries.

The fact that most of the cost of activities was assumed by the beneficiaries shows their interest in the programme. Furthermore, the fact that there are always candidates to host COMPAL events reflects continuity of activities. However, disparities in development, experience and capacities are evident among beneficiaries. Whereas this constitutes the strength and diversity of the programme, it also means that not all members can afford to travel abroad to attend meetings or to host an event. The programme's future will ultimately rely on the commitment of its most powerful members in taking the lead. The COVID-19 pandemic implied a shift of technical cooperation and capacity-building activities towards the online world, which can possibly entail cost reductions. For example, INDECOPI volunteered to relaunch the INDECOPI-COMPAL School for online courses in order to increase efficiency. However, even online activities need staffing, which still constitutes a significant cost for any technical cooperation project.

The EU is engaging more closely with Latin America. It has recently reached a political agreement with members of MERCOSUR, thus adding to existing ties with Central American and Andean countries. As trade integration increases, so will interest in consumer protection. The EU will benefit from ensuring an adequate level of consumer protection and product safety in exporting Latin American countries; it will also benefit from a level playing field for businesses that would apply a common set of consumer protection standards and practices. These two trends should attract the EU's interest in strengthening consumer protection in Latin America. In parallel, the EU is the fourth largest donor globally, with total official development assistance (ODA) standing at US\$16.4 billion in 2018. ${ }^{12}$ The EU can thus more easily mobilize resources to support regional initiatives which have a clear multiplier effect. It seems fitting that the EU and UNCTAD should partner to expand COMPAL activities to ensure better consumer protection in Latin America.

\section{Conclusion}

UNCTAD's COMPAL Programme had a significant and positive impact in improving consumer protection regimes and institutions in Latin America. It channelled EU best practices on consumer protection raging from electronic commerce to dispute resolution and financial services and simultaneously contributed to institutional strengthening and regional cooperation. UNCTAD is the focal point of consumer protection within the United

\footnotetext{
${ }^{12}$ https://donortracker.org/country/eu?gclid=EAIaIQobChMI5NCv7M615AIVxZTVCh0tmAvsEAAY ASAAEgIGLfD_BwE (accessed 3 September 2021).
} 
Nations, and it has ample experience in implementing technical cooperation programmes in this field. The EU is building closer ties with Latin America and is a champion of development aid. The EU and UNCTAD should partner in continuing and expanding COMPAL in the years to come for the benefit of Latin American and European consumers.

\section{Declarations}

Conflict of Interest The author declares no competing interests

\section{References}

\section{Legislation}

Devfin Advisers. (2012). Evaluation of COMPAL.

(AECID) (2019). Spanish cooperation training centres. Agencia Española de Cooperación Internacional para el Desarrollo.

COMPAL. (2018a). Cooperación entre los miembros de COMPAL.

COMPAL. (2018b). Guía para facilitar al sector empresarial el cumplimiento legal de sus obligaciones y derechos en materia del marco jurídico de protección al consumidor y competencia económica (Colombia).

COMPAL. (2018c). Manual preliminar para facilitar al sector empresarial el cumplimiento legal de sus obligaciones y derechos en materia del marco jurídico de protección al consumidor y competencia económica (Perú).

UNCTAD. Note by UNCTAD secretariat. TD/B/C.I/CPLP/6. United Nations Conference on Trade and Development.

UNCTAD. (2008) Report of the United Nations Conference on Trade and Development on its twelfth session. TD/442. United Nations Conference on Trade and Development.

UNCTAD. (2021). The Bridgetown Covenant. TD/541/Add.12 United Nations Conference on Trade and Development.

UNCTAD. (2017). Framework for voluntary peer reviews on consumer protection law.

UNCTAD. (2019). Review of capacity-building in and technical assistance on competition and consumer protection law and policy. TD/B/C.I/CPLP/19. United Nations Conference on Trade and Development.

\section{European Union}

Directive 2013, 11 EU on alternative dispute resolution for consumer disputes and amending Regulation (EC) No 2006, 2004 and Directive 2009, 22, EC(2013)OJ L 165., 2013Directive 2013/11 EU on alternative dispute resolution for consumer disputes and amending Regulation (EC) No 2006/2004 and Directive 2009/22/EC (2013) OJ L 165

Directive 2000/31 EC on certain legal aspects of information society services, in particular electronic commerce, in the Internal Market (2000) OJ L 178

Directive 2011/83 /EU on consumer rights, amending Council Directive 93/13/EEC and Directive 1999/44/ EC and repealing Council Directive 85/577/EEC and Directive 97/7/EC of the European Parliament and of the Council (2011) OJ L 304

EU Directive 2013/11 on alternative dispute resolution for consumer disputes and amending Regulation (EC) No 2006/2004 and Directive 2009/22/EC (2013) OJ L 165

Regulation 524/2013 on online dispute resolution for consumer disputes and amending Regulation (EC) No 2006/2004 and Directive 2009/22/EC (Regulation on consumer ODR)(2013) OJ L 165 


\section{UNCTAD}

Voluntary peer review of consumer protection law and policy in Indonesia, UNCTAD/DITC/CPLP/2019/1 $-(2019)$

Voluntary peer review of consumer protection law and policy: Morocco, UNCTAD/DITC/CPLP/2018/1 (2018)

Voluntary peer review on consumer protection law and policy: Perú, UNCTAD/DITC/CPLP/2020/1 $-(2020)$

\section{United Nations}

United Nations Guidelines for Consumer Protection, Resolution 39/248 (1985)

United Nations Guidelines for Consumer Protection, Resolution 70/186 (2015)

Publisher's Note Springer Nature remains neutral with regard to jurisdictional claims in published maps and institutional affiliations. 